\title{
Problems in the theory of scientific cognition of nature in the light of the sustainable growth concept
}

Concepts of sustained developed are being developed in the EU since 1983, when they had been defined for the very first time in a report called "Our Common Future", under the auspices of the World Commission on Environment and Development of the United Nations Organisation.

The foremost objective of the authors of this movement was to provide protection of biotic resources. In the period when concepts of sustainable growth were being established, natural sciences were going through a specific point of their development. Those sciences have to a certain extent made new definitions of their research practice. A practice which was not in the least based on a different contents of the posed assertions, but much more on adopted methods, thanks to which those assertions could be interpreted. Determination of correct principles which allowed the establishment of scientific methodology has become a basis of scientific knowledge pursuant to which various concepts could be formed, inter alia the concept of sustainable growth. Worthy of particular attention is the principle of Occam's razor which for the first time was defined by the English medieval theologian, William Occam. This scientist came to the conclusion that one should not increase, beyond what is necessary, the number of entities required to explain the reality. In its structure this principle not only defined the need of reducing the defined entities in the form of laws of nature, but also suggested the possibility of combining those laws, or their integration into the so-called universal laws. Establishment of laws created though such a merging process is a peculiar point in progress that takes place in development of a particular field of science. However, at the time when the concept of sustainable growth was being established, the development of natural sciences did not fully take the Occam's principle into consideration. Nonetheless at that time numerous scientists who were studying nature in a conscious way continued to choose an approach of scientific nature study in a much more complex way. Yet that approach was not in each case scientifically justified. Scientists who were 
studying physicochemical or biological processes found it much easier to explain the choice of this more complex scientific approach. Yet for scientists studying phenomena that comprised the factor of time and space such interpretation caused essential meritoric difficulties. The latter group comprises, inter alia, ecologists, palaeontologists or sedimentologists. In their interpretation of the laws of nature they have a need for a new dimension in the form of time and space. Consequently a specific "single-dimensional" image of the World, which sufficed to such groups of scientists as for example physicochemists, has become an essential limitation for the other ones. This group found that several laws of nature have a scope of applicability that is considerably limited both in time and in space. Beyond certain limits they are being replaced by other laws, which once again have their defined range within a delimited space and time continuum. The Occam's principle may also be applied to those theories which are established on the basis of the time and space dimension. Problems in application of the Occam's principle by scientists, such as for example ecologists, at the time when the concept of sustainable development was being established(the beginning of the eighties), affected to a certain extent the comprehension of the natural environment, as I have already mentioned in an article entitled "Concepts of sustainable growth in holistic natural education" (Problemy Ekologii, Bimonthly, No. 2/2007).

All the natural processes operating in the past are the same as those that can be observed operating in the present. This principle is better known as geological actualism, or uniformitarianism, and most probably has become a basis for interpretations for the concept of sustainable growth, and also for comprehending the surrounding natural environment. One of the principles underlying the concept of sustainable growth is to assure such management of the natural environment and its resources that would allow the future generations to continue benefiting from that environment on the basis of the same natural resources, not diminished. From the scientific viewpoint basing the concept of sustainable growth on this principle causes numerous significant uncertainties. If those ideas are to be based on scientific methodology, they have to be subject to the so-called testability principle. A universally adopted rule, which defines borders in sciences, is the mentioned principle of testability of scientific theories by empiricism. In its essence the concept of sustainable growth has become a certain scientific theory, related to an a priori defined future picture of the natural environment. This idea has been augmented by numerous 'scientific theories', which from the viewpoint of the objective they are expected to fulfil are nevertheless in advance in conflict with empiricism. For this reason they may not be used as reliable scientific material. Founding the concept of sustainable growth on such deductive reasoning is certainly absolutely erroneous and surely would not lead us to scientific cognition of nature. As is generally known theories 
in which conclusions may not be tested in an empirical way are devoid of any scientific grounds.

The establishment of scientific grounds for the concept of sustainable growth was consequently based partly on prediction, i.e. anticipation of the future condition of the natural environment pursuant to the knowledge of its present condition and laws that govern its transformations. From the scientific viewpoint this solution, however, proves to be in a certain sense defective and in many cases simply does not succeed. The inadequacy of this solution is simply that it is not always feasible to foresee what the future changes in the natural environment would be like. For the same reasons it is not possible to foresee the further course of evolution on Earth either. The great abundance of processes, systems and unforeseeable environmental interactions gives us a rather illusory impression as regards establishment of scientific theories, this time tested on the basis of retrodiction, or in other words postdiction.

Further scientific barrier that poses serious problems in nature based cognition is the so-called theory of integration levels. This theory presumes that it is impossible to foresee properties of a higher level when merely properties? of a lower rank are known. Hence it is not possible to foresee the properties of water when only features of hydrogen and oxygen are known, and similarly it is not feasible to anticipate possible features of ecosystems pursuant to knowledge concerning attributes of isolated population only. This has pronounced consequences in establishing first of all cognition of the scientific natural environment, which continues to be focused on those lowest integration levels. This results inter alia from the fact that sciences which handle those higher levels of biological organisation, such as for example ecology, have become separated relatively late from Biology, for which the main spheres of interest comprised such elementary fields of study as molecular biology, development biology, genetics, or taxonomy fields such as bacteriology, botany or entomology. The mentioned spheres of biological sciences have become fully focused on solving problems on the so-called basic level, i.e.: chemical compounds, intracellular organelles, cells, organs, organ systems, and finally on the entire organism. Pronounced disinclination towards solving problems from higher levels of biological organisation was due over a longer period of time first of all to empirical difficulties. Those difficulties were overcome as ecology, in which the main point of interest were subsequent levels of biological organisation, continued its development. Ecology took up fields of biological organisation which until that time were practically unknown. Studies were instigated on the level of population, ecological group or ecosystem. Naturally also in this case the level of scientific cognition is strictly adapted to the level of biological organisation. As the level of biological organisation continued to develop, the level of scientific cognition clearly decreases. This correlation significantly affects the establishment process 
of the concept of sustainable growth. When working out a scientific basis for this idea first of all use should be made from achievements in science on those highest levels of biological organisation, which, as I have already mentioned, are nonetheless the least studied from the research viewpoint. This also results from the fact of negligence of the holistic approach in development of the scientific cognition of nature. The holistic approach has already become naturally embedded in the elements of ecology. After all, what was the so-called "natural history", which comprising describing entire vegetation formations found on Earth and the animal species related to them functionally. The remaining fields in ecology, which have become separated from it, also tend to have a clearly holistic approach in establishing their scientific methodology. This concerns both the functional ecology, as well as evolutional ecology. Hence even today we find it difficult to comprehend fully why when establishing the meritoric basis for the concept of sustainable growth, the approach to the environment is not holistic at all. Focusing in the first place on the biotic environment caused profound consequences for the condition of numerous ecosystems. Consequences of many erroneous decisions taken in those times are visible even now, as was emphasised by the Austrians in the first six months of 2006, during their EU presidency. Long-term underestimation of the role also played by the abiotic environment was one of the errors in creating the concept of sustainable growth. There can be no ecosystem without a biotope. An analysis of the history of creating the concept of biotope in ecology shows that the very same mistake was made in establishing the notion of sustainable growth. Many years had to go by in ecology before it was understood that trophic relations concern not only organisms that make up the biocenosis, but also concern to a not lesser extent the inanimate environment of a biocenosis. With time this inanimate environment was called a biotope, and in 1935 Tansley could for the first time introduce the concept of ecosystem. The ecosystem as such has not become a subject or point of relation in the concept of sustainable growth straight away. The absence of sufficient comprehension of abiotic problems is in this concept practically visible even today. Most probably there are several reasons for that. On the one hand those are reasons of purely ecological nature, and on the other hand they result from multidimensional character of sustainable growth. In the ecological nature a system of relation was sought in the environment, which is a system that is the most self-sufficient as regards for example matter and energy. Biosphere is certainly such a system. For this reason the biosphere has become such a system of relation with all the resulting consequences. When establishing concepts of sustainable growth on the basis of this particular system it was easy to introduced certain postulates, however, due to there being a very low level of scientific cognition of this system and due to problems in the scope of empiricism all the propagated theories related to sustainable growth would remain in the sphere of far fetched suppositions 
that are not supported by scientific arguments within the concept. To a certain extent this is understandable from the viewpoint of general presumptions for this concept. It is not easy to define tasks for ecosystems within it at a time when we are creating a concept of a transnational nature. A concept, in which we refer to resources of the entire Earth, including the entire humankind that presently inhabits it, as well as future generations. When establishing such an extensively comprehended concept it is practically not feasible to have it founded on a solid basis of scientific cognition of nature. What is more one should not forget its multidimensional nature, which on the one hand is its strength, and on the other hand leads to additional internal meritoric conflicts on various planes of reference. Conflicts connected among others on different understanding of the same scientific terms. It is impossible to combine within a single idea of a clearly scientific nature problems from such distant disciplines, as for example technique, morality, economics, law or finally politics.

In formation of the concept of sustainable growth of key importance is the philosophical background. It is Ecophilosophy that defies the hitherto dominating views based on anthropocentrism. Belief in unlimited possibilities of man, unlimited usage of environmental resources gives away to new views in which man becomes only one of the numerous elements of Biocenosis. In the biocentric approach man and nature should continue to develop in a harmonious way. Such a way of thinking has become a basis for a new kind of philosophy, and namely ecophilosopy. Ecophilosophy in which considerable symbiosis between man and the environment has also become grounds for lasting sustainable growth. Full independence of resources coming from the environment proved to be purely a myth. Precursors of such a way of thinking were numerous philosophers. In the majority of cases their way of comprehending ecophilosophy stems from profound criticism of technical civilisation and endeavours aimed at its modification. From the present perspective it is rather difficult to find in a peremptory way who the actual precursor for the new biocentric approach to the environment was. Was it the philosophers, who intensified their criticisms of a technical civilisation, or perhaps the ecologists. Yet it is clear that those two ways of thinking have ultimately allowed the necessary assumption for an undertaking of a new social and political reality in which apart from economic factors, an appropriate position was also found by problems related to the natural environment. Ultimately this has become possible, thanks to establishment of a sustainable growth programme, this time based on politicians who gave this project an international rank.

Until today no precise scientific definition has been worked out for the concept of sustainable growth. This is certainly caused by a multitude of difficulties, not only of a meritoric nature. It is a programme which on the one hand satisfies certain political needs, by constituting a convenient and at the same time medial 
propaganda tool. Yet on the other hand very serious problems exist as regards scientific cognition of nature (as I have already written in the first part of this article) which form a meritoric barrier for establishing a scientific basis in the idea of sustainable growth. A basis founded on the above mentioned concept of biocentrism. A concept that revaluates our relation towards the environment. Concept in which ecophilosophers define a new hierarchy of values, for which first of all values connected with the biosphere should be of importance, and not as up to now values of the world of humans. It is impossible to develop further the concept of sustainable growth without performing concurrently scientific research related to get to know laws according to which the environment is being governed. That research must not only have the nature of holistic research to allow their fulfilling needs of the concept of sustainable growth, but should furthermore be based on elementary scientific paradigms, such as for example empiricism and the "Occam's razor". As a consequence of failure to conform to those requirements concepts of sustainable growth shall only remain in the sphere of social and political divagations, remaining in the best case merely a convenient tool used exclusively by politicians.

\section{Bibliography}

D. Botkin, E. Keller,1995; Environmental Science, John Wiley \& Sons INC, New York, s. 625.

J. DzIK, 2003; Dzieje zycia na Ziemi, Wydawnictwo PWN, Warszawa, s. 522.

J.M. DoŁęGA; Stowo o terminie Ekofilozofia, Studia Ecologiae et Bioethicae, UKSW, t.3, 2005, Warszawa, s. 499-505.

Ch.J. KREBs, 1996; Ekologia, Eksperymentalna analiza rozmieszczenia i liczebności, Wydawnictwo PWN Warszawa, s. 730.

E.P. Odum, 1982; Podstawy ekologii, Wydawnictwo PWRiL, Warszawa, s. 661.

A. Pawlowski, 2006; Wielowymiarowość rozwoju zrównoważonego, Problemy Ekorozwoju, vol. 1, nr. 1, s. 23-32.

Z. PiąTEK, 2007; Filozoficzne podtoże zrównoważonego rozwoju, Problemy Ekorozwoju, vol. 2, nr 1 , s. $5-18$.

J. SANDNER, 2006; Environmental protection concept in holistic nature studies education, Studia Ecologiae et Bioethicae, UKSW, t.4, 2006, Warsaw, s. 377-385.

J. SANDNER, 2007; Idee rozwoju zrównoważonego w holistycznej edukacji przyrodniczej, Problemy Ekologii 2/2007, ROK XI - Nr 2 (62) - marzec-kwiecień 2007, s. 71-75.

J.CSMuts, 1926: Holism and Evolution, Macmillan Co., New York. 


\section{STRESZCZENIE}

Autor w artykule pt. „Problemy teorii naukowego poznania przyrody w świetle idei zrównoważonego rozwoju”, podjął rozważania nad problematyką w zakresie obowiązujących w nauce teorii naukowego poznania przyrody i ich roli w budowaniu podstaw naukowych idei zrównoważonego rozwoju. Jako punkt wyjścia w swoich rozważaniach oparł na zasadzie brzytwy Occama, która po raz pierwszy została sformułowana przez angielskiego średniowiecznego teologa Williama Occama. Zasada ta w swojej strukturze, nie tylko definiowała potrzebę zmniejszenia opisywanych bytów w postaci praw przyrody, ale również sugerowała, możliwość łączenia tych praw, lub scalania w tzw. prawa uniwersalne. Inną niezwykle ważną zasadą, która została poruszona w artykule jest zasada testowalności. Powszechnie przyjętą regułą, określającą granice nauki jest wspomniana zasada testowalności teorii naukowych przez empirię. Idea zrównoważonego rozwoju w swojej istocie, stała się pewną teorią naukową, odnoszącą się do zdefiniowanego, a priori przyszłego obrazu środowiska przyrodniczego. Idea ta, obudowana została wieloma "teoriami naukowymi”, które z punktu widzenia celu, jaki mają spełniać są jednak z góry sprzeczne z empirią, dlatego też nie mogą służyć, jako wiarygodny materiał naukowy.

W wyjaśnianiu problemów teorii naukowego poznania przyrody w świetle idei zrównoważonego rozwoju autor posłużył się zasadą uniformitarianizmu, bardziej znaną pod hasłem aktualizmu geologicznego, która stała się prawdopodobnie jedną z podstaw w interpretacji idei zrównoważonego rozwoju. Tworzenie podstaw naukowych dla idei zrównoważonego rozwoju, oparło się więc częściowo na predykcji, czyli przewidywaniu przyszłego stanu środowiska przyrodniczego, wnioskując na podstawie znajomości jego obecnego stanu i rządzących jego przekształceniami praw. Rozwiązanie to $\mathrm{z}$ naukowego punktu widzenia, okazuje się jednak również w pewnym sensie ułomne i w wielu przypadkach po prostu się nie sprawdza. Ułomność tego rozwiązania polega po prostu na tym, że nie zawsze, można przewidzieć przyszłe zmiany środowiska przyrodniczego. Tak jak z tych samych przyczyn, nie można dzisiaj również przewidzieć dalszego przebiegu ewolucji na Ziemi. Ilość procesów, systemów i nieprzewidywalnych interakcji środowiskowych, daje nam raczej dość iluzoryczne wrażenie w zakresie budowania teorii naukowych, tym razem testowanych w oparciu o retrodykcję, czy inaczej postdykcję.

Nie ma, możliwości dalszego rozwijania idei zrównoważonego rozwoju, bez prowadzenia równoległych badań naukowych w zakresie poznawania praw jakimi rządzi się środowisko. Badania te muszą mieć, nie tylko charakter badań holistycznych, tak aby spełniać potrzeby idei zrównoważonego rozwoju, ale również powinny opierać się na podstawowych zasadach nauki, tzn. empirii oraz „brzytwie Occama”. Nie zastosowanie się do tych wymogów spowoduje, że idee zrównoważonego rozwoju, pozostaną jedynie w sferze społeczno-politycznych dywagacji, stanowiąc w najlepszym przypadku, wygodne narzędzie wykorzystywane wyłącznie przez polityków. 